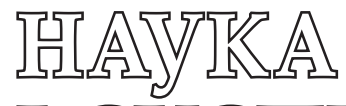

doi: https://doi.org/10.15407/visn2021.08.029

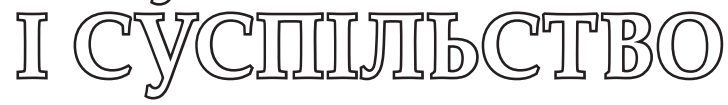

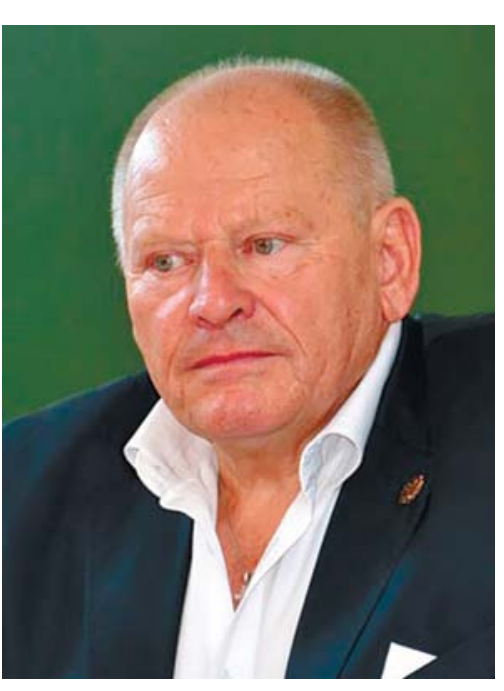

Жулинський

Микола Григорович академік НАН України, директор Інституту літератури ім. Т.Г. Шевченка НАН України

\section{АКАДЕМІЧНИЙ РУХ ДО НЕЗАЛЕЖНОСТІ УКРАЇНИ}

Автор статті ділиться своїми спогадами про зародження громадсько-політичної організащії «Народний рух України за перебудову», або просто Руху, в якому визначальну організачійну і програмотворчу роль відіграла украйнська наукова й творча еліта. Рух став головним рушієм демонтажу збанкрутілого комуністичного режиму та відродження державності України, набуття нею статусу незалежної, суверенної держави і значною мірою вплинув на визначення шляхів соціально-економічного розвитку $i \epsilon 8$ ропейської інтегращії України.

Віра - світло, що в темряві бачить... Григорій Сковорода

Дев’яте вересня 1989 року. Другий день роботи Установчого з’їду Народного руху України. Я сиджу за спиною завідувача ідеологічного відділу ЦК Компартії України Леоніда Кравчука і раз у раз поглядаю на нього. Бачу, хвилюється, але уважно вслухається в кожен виступ з трибуни. Запитую, чи буде він виступати. «Якщо запросять, дадуть слово - виступлю», - не повертаючись до мене, сказав Леонід Кравчук.

Звісно, йому було чого хвилюватися. Не знав, як сприйме його, головного ідеолога українських комуністів, патріотично сконсолідований зал, але досвід публічних дискусій між КПУ і Рухом, у яких брали участь передусім співробітники Академії наук Мирослав Попович, Віталій Дончик, В'ячеслав Брюховецький та ін., допоміг йому втихомирити збурених появою на трибуні їхнього опонента делегатів з’їзду. Адже за десять днів до публікації Програми Народного руху України за перебудову Леонід Кравчук виступив одночасно по радіо і телебаченню 3 різкою критикою програми майбутньої громадсько-політичної організації, що спровокувало знавіснілу кампанію з дискредитації Руху в партійній та комсомольській пресі, на радіо і телебаченні. Ніхто з борців за збереження єдиної в країні партії - КПРС - не бачив і не читав Програми Руху, але кинувся всіляко дискредитувати Рух з єдиною метою: не допустити виникнення альтернативної КПРС масової, загальноукраїнської організації, здатної повести за собою народ. 


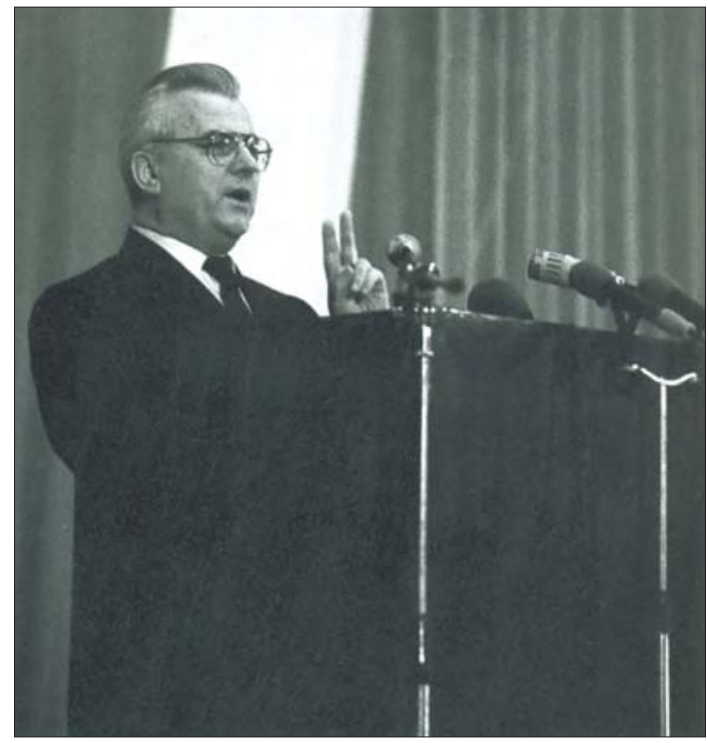

Леонід Кравчук

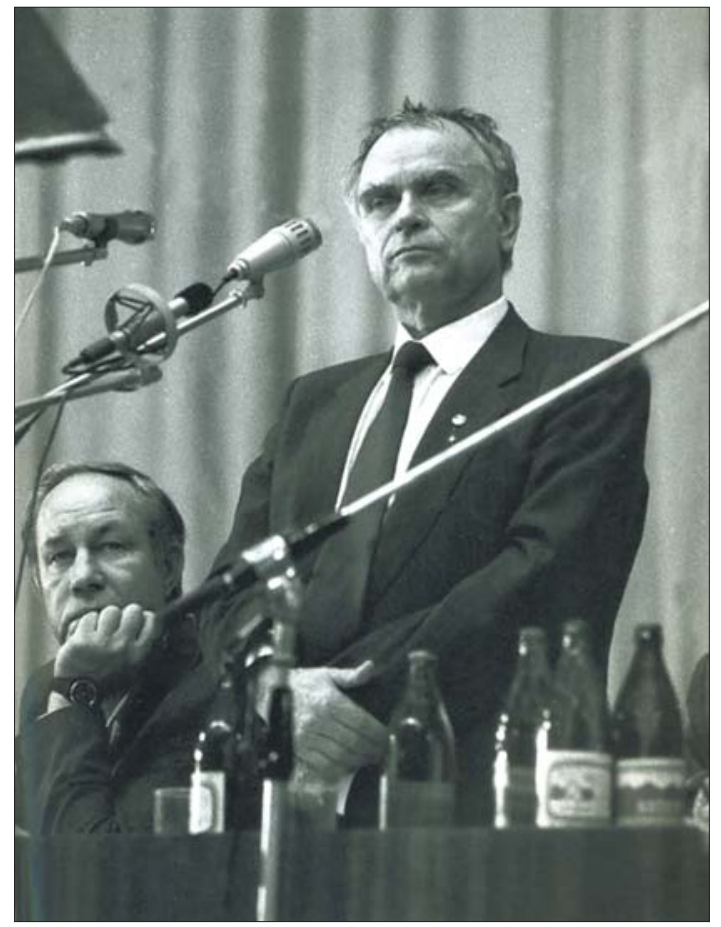

Дмитро Павличко
Головуючий на цьому засіданні з’їзду Дмитро Павличко запрошує до виступу Леоніда Макаровича. Той несподівано знімає з лацкана піджака значок народного депутата і йде до трибуни. Спокійний, впевнений - має досвід дискусійного спілкування з рухівцями. Лише за останніх пів року тричі виступав на різних зібраннях Народного руху за перебудову, вів телевізійні діалоги з ученими і письменниками. Закликає до порозуміння, до єдності: «щоб ми боролися не проти один одного, а за спільну справу». Зал аплодує. А що це за спільна справа, заради якої він, «християнин і комуніст», запрошує Народний рух України до співробітництва з Компартією? Комуніст Леонід Кравчук добре усвідомлює, де, в якій аудиторії, в який час і від імені якої партії він виступає.

Минуло вже чотири роки від початку проголошеної Михайлом Горбачовим перебудови, але, як висловиться на з'їзді недавній політв'язень, кочегар Михайло Горинь, ці «чотири роки перебудови не перетворили Радянський Союз на правову державу, Україну - на суверенну республіку, а її населення - на вільних громадян, захищених законом і рівних перед ним».

Завідувач ідеологічного відділу ЦК Компартії України уважно слухав усіх, хто виголошував доповіді або виступав в обговоренні, тому у своєму виступі повсякчасно наголошує на необхідності дотримуватися елементарних порядків і законів, жити «силами правової держави». Компартія боїться передусім революційного вибуху, прагне якось увести в спокійне русло бурхливу стихію народного обурення збанкрутілою всесоюзною партійною владою.

Леонід Кравчук чи не єдиний із республіканського партійного керівництва бачить, що перебудова пробудила національну гідність українця, в дискусіях з рухівцями чітко увиразнилася головна ідея і мета нового громадсько-політичного руху - побудова суверенної Української держави. Щоправда, з певним компромісним уточненням: у складі оновленого СРСР за умови укладання нового Союзного договору. На цьому наголосить у своєму виступі на з”ізді голова Західного наукового

ISSN 1027-3239. Visn. Nac. Acad. Nauk Ukr. 2021. (8) 
центру АН України академік АН України Ігор Юхновський: всі помисли конференції мають бути спрямовані на досягнення однієї головної мети - «це побудова суверенної Української республіки у складі радянської федерації».

Цю ж думку проголосить на Установчому з’їзді Народного руху України Іван Дзюба, який буде обраний академіком АН України в 1992 році: «Рух - знову-таки, на мій погляд, - повинен твердо заявити, що майбутню Україну ми бачимо як суверенну - політично, економічно і культурно суверенну - державу, що входитиме на підставі нового Союзного договору в реформований Союз Радянських Соціалістичних Республік». Зал цю ідею схвалює оплесками.

Така програмна мета Руху цілком улаштовує республіканське партійне керівництво, тому Леонід Макарович у своєму першому виступі на Установчому з’ізді під бурхливі оплески висловить, як він вважає, спільну надію: «Щоб ми прийшли до суверенної України». Він знає, що серед делегатів і гостей з'ізду, а їх число сягає 1129 чоловік, тільки одних делегатів 914, і більшість учасників з'ізду - наукова і творча еліта України. Лише одних працівників науки - 121, серед них лауреати Державних премій СРСР, 6 лауреатів Державної премії УРСР, 3 академіки і 2 члени-кореспонденти Академії наук, 28 докторів наук, 96 кандидатів наук. 800 делегатів - люди 3 вищою освітою (72\%). А якщо згадати, що серед делегатів ще 104 працівники культури, представники всіх творчих спілок, громадських організацій, то для Леоніда Кравчука було очевидним, якою ідейно сконсолідованою і критично налаштованою щодо компартійної влади була ця переважно наукова і творча еліта.

Нагадаймо: Академія наук України була представлена на Установчому з’ізді Народного руху України за перебудову такими науководослідними установами, як Інститут літератури ім. Т.Г. Шевченка, Інститут кібернетики, Інститут фізіології рослин, Інститут історії, Інститут археології, Інститут фізики, Інститут проблем онкології ім. Р.С. Кавецького, Інститут теоретичної фізики, Інститут металофізи-

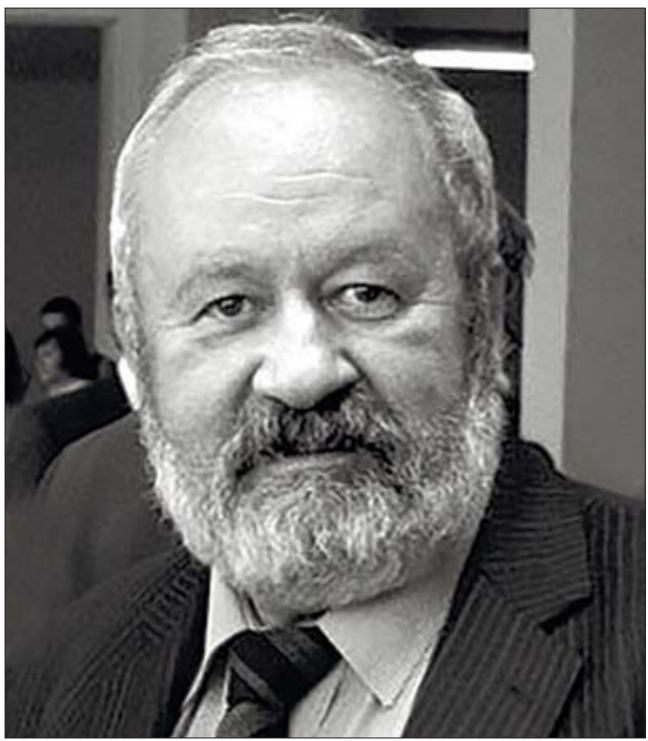

В'ячеслав Брюховецький

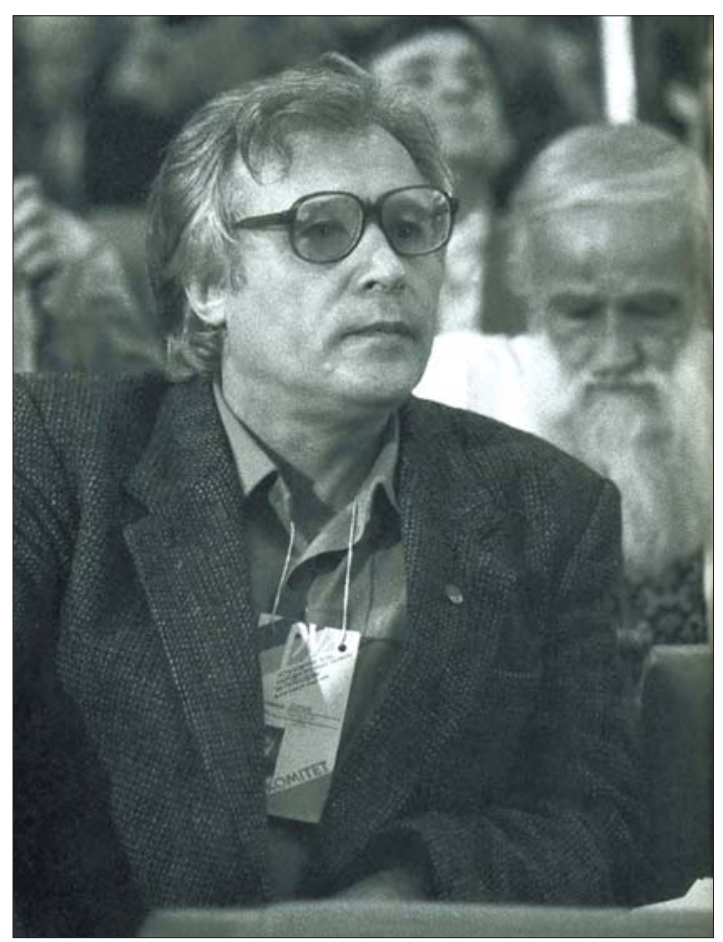

Віталій Дончик 


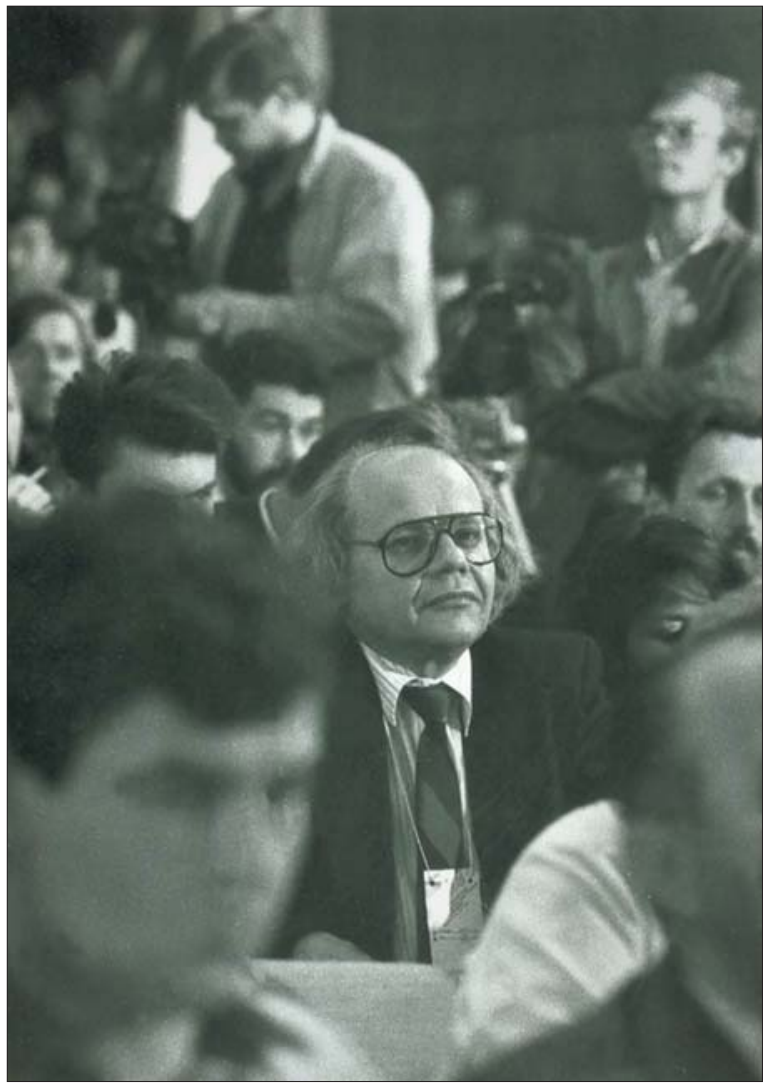

Іван Драч

ки, Інститут ботаніки, Інститут зоології, Інститут надтвердих матеріалів, Інститут ядерних досліджень, Інститут математики, Інститут біохімії, Інститут держави і права, Інститут електродинаміки, Інститут органічної хімії, Головна астрономічна обсерваторія, Інститут суспільних наук, Інститут прикладних проблем механіки і математики, львівський Фізико-механічний інститут.

Вчених Академії наук було обрано на Установчому з'їді до керівних органів Руху - до Великої Ради Руху, вони очолили або увійшли до складу колегій (політико-правової; соціально-економічної; культури, науки, освіти; науки; екологіï), до Редакційної комісії Великої Ради (ії головою було обрано доктора філологічних наук Віталія Дончика), Секретаріату Руху. Це - економісти Володимир Черняк, Веніамін Сікора, Михайло Швачка, філософ Мирослав Попович, юрист Володимир Васи- ленко, математики Павло Кислий, Орест Влох, астроном Леонід Шульман, біологи Михайло Голубець, Микола Бідзіля, Ярослав Мовчан, соціолог Володимир Паніотто.

Отже, ідейно-організаційним ядром Народного руху України була наукова і творча інтелігенція, тому делегати Установчого з’ізду визнали, що Рух може розраховувати на підтримку більшості лише серед інтелігенціі.

I хоча в Рух прийшли люди різних світоглядних позицій і політичних орієнтацій, оскільки це громадсько-політичне об’єднання було на той час єдиною силою, яка прагнула замінити збанкрутілу комуністичну партійнорадянську систему, проте цей державотворчий народний здвиг започаткувала, організувала i повела наукова й творча інтелігенція.

Організаційні витоки Народного руху України криються в академічному середовищі, а саме в Інституті літератури ім. Т.Г. Шевченка АН України, в якому вже восени 1988 року було створено ініціативну групу на чолі з ученим-літературознавцем, тодішнім секретарем парторганізації Інституту В’ячеславом Брюховецьким та попереднім секретарем парторганізації Інституту Віталієм Дончиком.

Саме вони, академічні вчені В’ячеслав Брюховецький і Віталій Дончик та їхні однодумці з Інституту літератури ім. Т.Г. Шевченка разом з письменниками, передусім Іваном Драчем, були ініціаторами і мозковим ядром, у якому народилася і сформувалася ідея та план створення альтернативної КПРС громадсько-політичної організації.

Слід наголосити, що перше нелегальне організаційне засідання, присвячене створенню громадсько-політичної організації на зразок польської «Солідарності» та литовського «Саюдіса», відбулося 3 ініціативи голови Київської письменницької організації Івана Драча. На нього було запрошено вчених Академії наук України В’ячеслава Брюховецького, Віталія Дончика, Миколу Жулинського, Юрія Цекова та письменників Сергія Гречанюка, Станіслава Тельнюка і Володимира Маняка. Згодом, у березні 1989 року, вчені-літературознавці увійшли до складу Координаційної ради Народ-

ISSN 1027-3239. Visn. Nac. Acad. Nauk Ukr. 2021. (8) 
ного Руху України м. Києва, головою якої було обрано доктора філософських наук з Інституту філософії АН України Мирослава Поповича.

Отже, передусім академічна ініціативна група під керівництвом завідувача відділу історії української літератури доктора філологічних наук Віталія Дончика у співпраці з письменниками і почала розробляти проєкт Програми і Статуту майбутнього Руху. Перший проєкт Програми та Статуту підготували вчені-літературознавці В'ячеслав Брюховецький i Biталій Дончик, письменники Петро Осадчук і Віктор Терен. До них долучилися співробітники Інституту літератури ім. Т.Г. Шевченка та письменники Юрій Цеков, Наталія Мазепа, Володимир Мельник, Юрій Ковалів, Володимир Моренець, Іван Драч, Дмитро Павличко, Іван Дзюба, Василь Яременко, Юрій Мушкетик, Павло Мовчан, Володимир Яворівський, Анатолій Шевченко, Олександр Лук'яненко, Михайло Слабошпицький, Сергій Гречанюк, Григорій Клочек, Станіслав Тельнюк, Ігор Малишевський, Володимир Маняк. Звісно, залучали до роботи, як консультантів, і професіоналів з позаакадемічного і позаписьменницького кола.

...Ніколи не забуду того вечірнього, у понеділок 30 січня 1989 року о 18-й годині (важливо було, щоб ці збори відбулися в неробочий час), засідання загальних зборів наукового колективу Інституту літератури ім. Т.Г. Шевченка АН України, на якому було винесено для обговорення проєкт Програми Народного Руху України для сприяння перебудові і Статут Руху. Про ці збори та про порядок денний стало відомо всім партійним органам - райкому партії, міськкому, ЦК. Їхні представники вже товклися в невеличкому залі засідань Інституту літератури, їх ледве вдалося розмістити. Зачитати текст Програми і Статуту майбутньої громадсько-політичної організації вирішили доручити моєму аспірантові, колишньому радіожурналісту Сергію Іванюку.

Такого бурхливого обговорення, таких гарячих дебатів, емоційних збурень і пристрастей цей зал ще ніколи не бачив. Представник ЦК компартії кандидат філософських наук Ми-

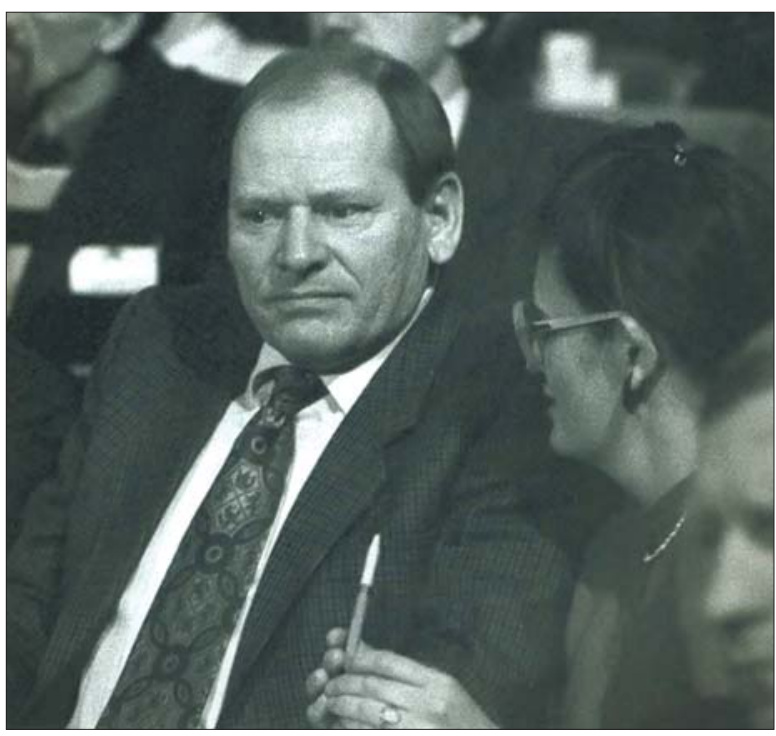

Микола Жулинський

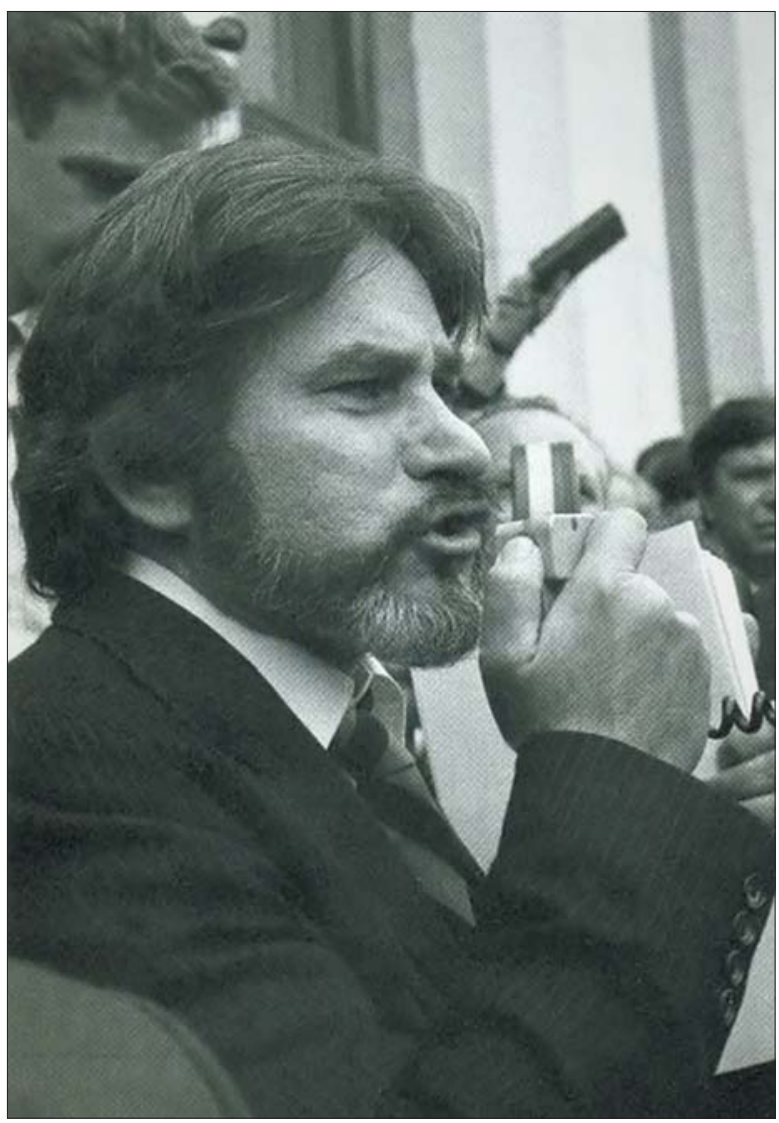

Павло Мовчан 


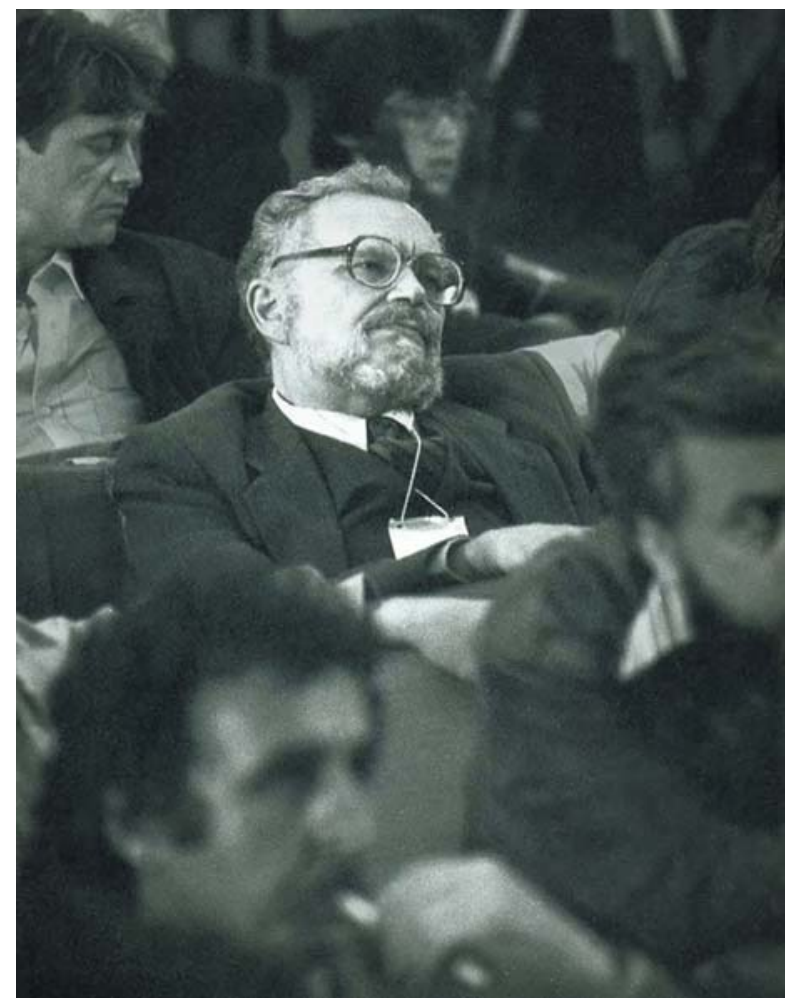

Мирослав Попович

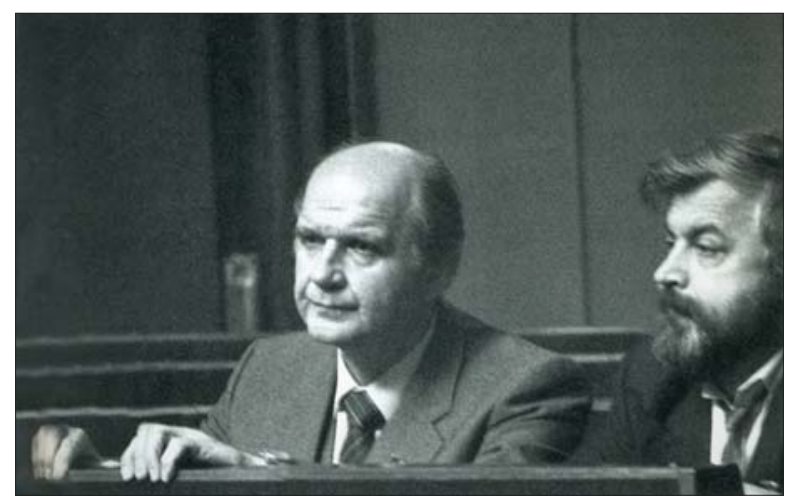

Ігор Юхновський

кола Шульга (нині відомий вчений-соціолог) був незадоволений тим, що у Програмі Руху проігноровано керівну роль компартії.

Нарешті голосування: проти - лише один («Я змушений був голосувати проти», - скаже згодом директор Інституту літератури Ігор Дзеверін), утрималися - троє, всі інші, понад 100 співробітників Інституту - за.
На другий день вранці, у вівторок 31 січня, представники Інституту літератури ім. Т.Г. Шевченка АН України прибули до Будинку кіно, де зібралися київські письменники, і уповноважений від Інституту В'ячеслав Брюховецький оприлюднив резолюцію з повною підтримкою проєкту Програми і Статуту Народного Руху України за перебудову. Отже, колектив Інституту літератури 30 січня, а Київська письменницька організація Спілки письменників України - 31 січня 1989 року затвердили проєкт Програми і Статуту Народного Руху України за перебудову.

I лише 14 лютого 1989 року, коли на запрошення Леоніда Кравчука до його кабінету прибули Іван Драч, Дмитро Павличко, В’ячеслав Брюховецький та головний редактор «Літературної України» Борис Рогоза, партійна влада в особі Леоніда Макаровича дає дозвіл на друкування в органі Спілки письменників України проєкту Програми і Статуту Народного руху за перебудову.

Робота над вдосконаленням проєкту Програми Руху продовжилася в друкарні «Київської правди», куди 15 лютого 1989 року, напередодні виходу в світ «Літературної України» тиражем 100 тисяч примірників, прибули голова робочої групи зі створення Програми Віталій Дончик, В’ячеслав Брюховецький, Іван Драч, Дмитро Павличко, Борис Олійник, Борис Рогоза, Василь Плющ. Унаслідок цього, вже остаточного перед опублікуванням, редагування, зважаючи на присутність секретаря парткому Спілки письменників України Бориса Олійника, в Програмі Руху проглядалася лінія на заявлення лояльності до тодішнього режиму, зокрема щодо побудови стосунків 3 іншими республіками Союзу РСР на основі нового Союзного договору. Адже без цих компромісних положень навряд чи вдалося б оприлюднити цю основоположну рухівську програму. Щоправда, теза про новий Союзний договір з'явилася в Програмі пізніше, після обговорення та ухвалення іiі на Установчому з`ізді Народного Руху України.

Завідувач ідеологічного відділу ЦК Компартії України Леонід Кравчук усі три дні роботи

ISSN 1027-3239. Visn. Nac. Acad. Nauk Ukr. 2021. (8) 
з’їзду Руху був присутній у залі і знав, що його виступ слухатимуть тисячі людей, які стоять біля Палацу культури Політехнічного інституту. Тому він ще раз наголосить: «Щоб ми прийшли до суверенної України (бурхливі оплес$\kappa и)$. Щоб ми прийшли до суверенної України без будь-якої регламентації і обмежень (оплес$\kappa u)$, щоб наша державна мова українська була справді державною (оплески), але щоб ця мова, велика мова великого народу, щоб ніхто з присутніх на території інших народів і словом не міг сказати, і в думці не міг подумати, що ця мова утверджується за рахунок інших».

Леонід Кравчук знає, що в залі домінують представники легалізованих і новопосталих, але вже численних громадських організацій Товариства української мови імені Т.Г. Шевченка, «Меморіалу», Української асоціації захисту історичного середовища, Української Гельсінської спілки, «Зеленого світу», «Спадщини», Української асоціації незалежної творчої інтелігенції, Української народно-демократичної ліги, члени національно-культурних товариств: єврейського, російського, польського, вірменського, кримськотатарського, грецького, молдавського, угорського, болгарського, гагаузького, представники всіх творчих спілок, релігійних конфесій.

А головне, депутат Верховної Ради України Леонід Кравчук, звісно, зауважив, що в зачитаному завідувачем відділу Інституту літератури ім. Т.Г. Шевченка АН України Віталієм Дончиком проєкті Програми Народного руху України за перебудову головною метою діяльності Руху є «створення суверенної української держави, яка будуватиме свої стосунки з іншими республіками СРСР на підставі оновленого Союзного договору».

На той час заявлена в Програмі НРУ за перебудову ціль «сприяти розвитку національнодержавного будівництва, скерованого на перетворення Української РСР в демократичну правову державу», і мирним, демократичним шляхом виборювати незалежність України, нехай і в рівноправному союзі з іншими республіками СРСР, була для компартії оптимальним рішенням 3 метою уникнення револю- ційної конфронтації в республіці. Та головне, що силового протистояння з комуністичним тоталітарним режимом намагалися уникнути i творці-засновники Руху, прикриваючи свої справжні цілі перебудовними гаслами, формуючи свою програму перебудови українського суспільства, яка в основних своїх положеннях була альтернативною до політики КПРС.

...Наприкінці третього дня роботи Установчого з’їзду Народного руху України за перебудову головуючий на цьому засіданні Михайло Горинь знову надає слово Леоніду Кравчуку. I коли Леонід Макарович йде до трибуни, Дмитро Павличко вихоплює для себе з його короткого регламенту «два слова», намагаючись підготувати учасників з’їзду до толерантного сприйняття виступу завідувача ідеологічного відділу ЦК Компартії України. Він наголошує, що Кравчук дав дозвіл на видрук Програми Руху, допомагав Івану Драчу і йому в підготовці з’їду, сприяв прийняттю Верховною Радою України Закону про мови в Українській РСР, і акцентує: «Ми за співробітництво з партією».

Л.М. Кравчук майже слово в слово повторює те, що сказав Павличко: «Давайте співпрацювати. Знаходьмо... не йдімо на конфронтацію. За конфронтацією стоять сили. Не треба вже сили. Треба взаємного розуміння».

Дмитро Павличко знову експресивно «вривається» у виступ Леоніда Кравчука: «Ми тут зібралися створити і створили Народний рух України. Ми хочемо співпрацювати з партією, з іiі кращими силами, і реально, конкретно 3 Леонідом Макаровичем Кравчуком (оплески)».

Не судилося.

...І знову, як десять років тому, я сиджу в залі Палацу культури Київської політехніки і спостерігаю, як у президії цих урочистих зборів 3 нагоди 10-річчя від дня створення Народного Руху України Віталій Дончик і Дмитро Павличко перешіптуються з першим Президентом відродженої незалежної України Леонідом Кравчуком, який керував державою в перші надзвичайно складні чотири роки. Як згодом розповів Віталій Дончик, мова йшла про те, чому не відбулася співпраця Руху в ім'я розбудови держави з Президентом України. Адже 
Леонід Макарович Кравчук тоді, в часи створення Руху, запевняв, що опиратиметься на цю потужну громадсько-політичну силу, i, коли був обраний президентом України, запропонував Руху, вже як політичній партії, очолюваній В'ячеславом Чорноволом, сформувати уряд.

I вчений-літературознавець Віталій Дончик, і письменник Дмитро Павличко дорікали тоді Леоніду Макаровичу за те, що простягнута ним, Президентом України, рука Рухові для співпраці була лише ритуальним жестом, бо В'ячеслав Чорновіл - це далеко не весь Рух, що президент Кравчук почав залучати до своєї команди колишніх керівників-партократів, а згодом увійшов до одіозної СДПУ(о).

Але це вже інша історія, на розвиток якої Рух, уже в статусі політичної партії, не зміг суттєво вплинути.
Та роль Народного Руху України як громадсько-політичної організації визначальна у відродженні державності України, набутті нею статусу незалежної, суверенної держави та у визначенні шляхів соціально-економічного розвитку і європейської інтеграції України. Створення Народного Руху України - подія істинно історична, завдяки якій український народ заявив про себе як державотворча нація. Рухом українці утвердили своє невід'ємне право на гідне майбутнє української нації.

Народний Рух України, в якому визначальну організаційну і програмотворчу роль відіграла наукова і творча еліта, став головним рушієм демонтажу збанкрутілого комуністичного режиму, очолив процес національно-демократичного відродження та суверенізації України.

\section{Mykola H. Zhulinsky}

Taras Shevchenko Institute of Literature of the National Academy of Sciences of Ukraine, Kyiv, Ukraine

\section{ACADEMIC MOVEMENT TO THE INDEPENDENCE OF UKRAINE}

The author of the article shares his memories of the birth of the socio-political organization "People's Movement of Ukraine for Reconstruction," or simply Rukh, in which the Ukrainian scientific and creative elite played a decisive organizational and programmatic role. The movement became the main driver of the dismantling of the bankrupt communist regime and the revival of Ukraine's statehood, its acquisition of the status of an independent, sovereign state and significantly influenced the definition of ways of socioeconomic development and European integration of Ukraine. 